International Journal of English Literature and Social Sciences
Vol-6, Issue-2; Mar-Apr, 2021
Journal Home Page Available: https://ijels.com/
Journal DOI: $10.22161 /$ ijels

\title{
Man, and Culture Interface
}

\author{
Apar Kumar Lamsal ${ }^{1}$, Ram Prasad Pokhrel ${ }^{2}$
}

\author{
${ }^{1}$ Associate Professor, Department of NeHCA, TU, PG Campus, Biratnagar, Nepal \\ ${ }^{2}$ Lecturer, Department of Sociology, TU, PG Campus, Biratnagar, Nepal
}

Received: 21 Jan 2021; Received in revised form: 09 Mar 2021; Accepted: 25 Mar 2021; Available online: 22 Apr 2021

(C)2021 The Author(s). Published by Infogain Publication. This is an open access article under the CC BY license

(https://creativecommons.org/licenses/by/4.0/).

\begin{abstract}
Anatomical structure, nature, culture and personality are not exclusively separate entities but different aspects of human beings and all these aspects have circular rather than linear relationships. This article does not explain any detail on the process of this relationship based on field study. But, it mainly mentions the views of anthropologists in short. However, the researchers try to prove this relationship through some observational facts found in the experience of everyday life.
\end{abstract}

Keywords-Biology, Human Nature, Influence, Personality, Psychology.

\section{INTRODUCTION}

Man and culture are the two sides of the same coin. Neither man nor the culture can exist without the existence of others. Though 'superorganic' nature of culture is advocated by many anthropologists, it is neither originated nor useful of its function without the existence of human beings. A man without the culture is not so different from other animals. Man is a cultural animal. So, the research question of this article is how man and culture are influenced by each other.

\section{TERMINOLOGY}

The words 'man' and 'culture' are vague terms. So, for the analytic purpose, it is necessary to operationalize the word man and to accept any standard definition of culture too.

The word 'man' is, here, loosely used to denote the human being and human being denotes his threedimensional aspects : bio-psychological structure, nature, personality.

Gillin (1948 : 666) explains the bio-psychological foundation as 'constitutional characteristics' which is one of the sources of personality. According to him, constitutional characteristics subsume the three aspects mental ability, endocrine balance and body build. Young (1949 : 99-101) explains the bio-psychological foundation of personality as a receptive-nervous-response system and endocrine system. Sensory organs are receptors

whereas muscles, glands and tendons are effectors. Likewise, the central nervous system consists of the brain and spinal cord and the autonomic nervous system which controls the internal reactions of glands are two types of the nervous system. Endocrine system is the ductless glands that secrete a chemical substance called hormone. According to Warden (1936: 86), erect bipedism, manual dexterity, vocal language and superior intelligence are human's body and mind foundation on which human nature, culture and personality emerged.

Human nature, culture and personality are defined as three levels of uniqueness in human mental programming or mental software (thinking, feeling and acting) by Hofstede (Figure 1).

Human nature is a controversial concept among and within the different sciences. According to Malinowski, (1944: 75), human nature means the biological determinism which imposes on every civilization and all individuals in it the carrying out of such bodily functions like breathing, sleep, rest, nutrition, excretion and reproduction. He (1944 : 5) further categorizes human nature as vital sequence of three components namely impulse (physiological state of organism), act (physiological performance corresponding to impulse) and satisfaction (end-result of physiological performance). Hofstede (2010:6) defines human nature as inherited and universal mental programming of thinking, 
acting and feeling and compares it with a 'computer operating system' which determines the physical and psychological functioning of a human being. Some of the specific psychic processes of human being are the awareness of the external world and internal state, ability to remember and make plans and setting goals on the basis of memorization, selective retrieval of information acquired through the interaction with the environment, formulating abstract theories and building mental representations of reality. In this way, human nature can be defined as the capacity to function the body (physiology) and mind (psychology) of the human being.

Culture is organization of phenomena-acts (patterns of behavior), objects (tools), ideas (belief, knowledge) and sentiments (attitudes, values)-that are developed upon the use of the symbol (White, 1949 : 139140). Culture has both universal (etic) and specific (emic) aspects.

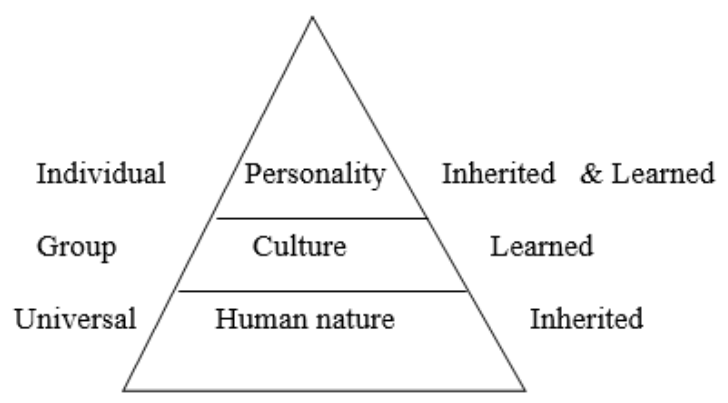

Fig.1: Three levels of mental programming

Source : Hofstede et al, 2010, p. 6)

Personality is defined in various disciplines such as psychology, social anthropology and cultural anthropology in different ways. Bidney (1953: 342) defined personality, in an anthropological sense, as a psycho-cultural action and reaction pattern, whether overt or covert, which is typical or characteristic of an individual (or organization of individuals) in the performance of his sociocultural role at a given stage of development. In this way, Bidney and Hofstede have a similar opinion regarding the nature of personality. Personality, according to Bidney (1953: 342), connotes a polaristic- psychocultural entity or it, according to Hofstede (2010:6), connotes polaristic- inherited and learned entity. Gillin (1948 : 666) defines personality as an individual's organizations of actions and tendencies to act (attitude) and accompanying emotions and tendencies to emotion. Linton (1936 : 464) is of the opinion that personality has been used to designate the whole of the individual's mental qualities i.e. the sum total of his rational faculties, perceptions, ideas, habits and conditional emotional responses. Every personality presents two aspects-content and organization (Gillin, 1948 : 666; Linton, 1936 : 464465).

\section{METHODOLOGY}

Basically, this article is prepared based on secondary documentary sources; however, the personal observations are also helpful.

\section{CONCEPTUAL FRAMEWORK}

Though this article concerns with the interrelationship of five aspects of man, it is divided into different categories in the binary poles. Firstly, one pole is represented by human nature and another pole is represented by culture. Secondly, one pole is represented by personality characteristics and another pole is represented by culture. Thirdly, one pole is represented by human nature and another pole is represented by personality. Fourthly, one pole is represented by anatomical structure and another pole is represented by culture. Human nature is basically inherited, culture is learned and personality is both inherited and learned. And, the bio-psychological structure of Homo sapiens is the foundation of all kinds of relationships. This article analyzes the reciprocal influences of opposite poles of different categories.

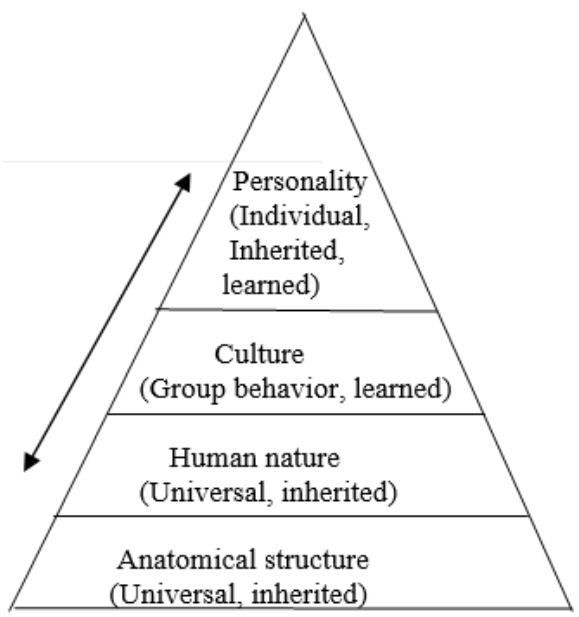

Fig.2: Interrelationship of binary poles

\section{ANALYSIS}

\subsection{Human biology and culture}

Hiebert (1976: 23-24) admitted that people's physical characteristics affect the kind of culture. For example, the small structure of Pygmies permits them to provide lower roofs for their shelters (ibid, 547). Bagby (1953: 547) also mentions physiological needs and race as 
some of the causes of culture. According to Lowie, race influences culture (1917: 7) but culture changes far more rapidly than race $(1947,9)$. Due to the racial differences, some traits of emic aspects of culture may emerge. But, the differences in cultural achievement cannot be regarded as significant for the determination of race (Beals and Hoijer, 1913 : 196). Menstruation is a biological phenomenon that is one of the causes of taboo-culture. Physical defects and disease limits contacts and consequent isolation may result in retarted culture (Reuter, $1946: 125$ ).

According to Bidney (1947: 387; 1953: 334) culture, in general, may be understood as the dynamic process and product of the self-cultivation of human nature. Count (1958: 1081) throws light on the relationship between culture and human nature by defining culture as the idioms for eliciting and expressing the innate nature of man. Culture is not a simple and direct manifestation of human nature (White, 1949 : xviii) but Human nature is the biological foundation of the cultural superstructure (Malinowski, 1944: 75; Warden, 1936: 17). Organic or neurological structure limits the type of culture for example health and disease provide organic conditions which help or retard the cultural evolution of the society (Bidney, 1947: 381-382). Human nature is a precultural or meta-cultural notion (Bidney, 1953: 336). The psychology of men such as pain and pleasure is not purely physical or biological facts but is modified by culture (Kluckhohn, 1944: 6). All cultural phenomena are natural phenomena modified by human effort and interaction (Bidney, 1953: 334).

Human biology is changed by pollution and much pollution is caused by human activity and human activity is directed by culture (Schell, 2014: 147). Body build may be modified by culture to a limited degree (Gillin, 1948 : 666). For example, food culture, costume culture, body decoration culture (i. e. tattoo) may permanently change the physical appearance as well as physiological and psychological characters of the individual. Health and disease are directly influenced by the food culture of the people. Births and deaths are organic facts that may be affected by culture. Marriage, trade and commerce, migration are cultural phenomena but they may be the cause of racial amalgamation.

Bidney and Shore also proposed the theory of the mutual relationship between human nature and culture in their own words. According to Bidney (1947 : 384) the relationship between culture and human biology is cyclical rather than linear because the organic conditions determine culture and culture as a superorganic achievement, which in turn, affects the organic condition. Shore (2001:31) says Human nature and culture are mutually and dialectically constitutive of human life or human nature encompasses the human capacity for and dependence upon culture.

Shore (2001 : 34) is of the opinion that human physiology and psychology are the product of natural and cultural selection. Three vital sequences of human nature impulse, act and satisfaction are remolded by tradition, for example, sexual impulse is modified by anatomical inroads, hunger satisfaction is different for Brahmin from others by eating the flesh of cow (Malinowski, 1944 : 8586). In this way, culture influence the biological process of human life.

The question may be raised that if human nature is universal then how cultural difference may occur. But, Shore (2001: 35) accepts the opinion that advocates human nature which is more stable as a human universal. Due to the universal nature of human nature, etic culture exists. Bidney (1944 : 35) believes that etic aspect of culture is an expression of universal human needs and emic aspects are development of potentialities of human nature concerning diverse geographical environments. Reuter (1946 : 121) emphasizes the universal physical, mental and temperamental features of the individual as the foundation of universal culture as well as variation in original character as sex, race and individual physical differences as the foundation of variation of culture.

Culture may play the role of either enhancing the biological fitness (for example food and housing habits, healing systems etc.) or decreasing the biological fitness (for example the effect of circumcision such as infections, high-risk pregnancies, difficulties at delivery, the transmission of infectious diseases to the newborn, impairment in sexual pleasure etc.) or without any role in biological fitness of human beings.

Clothing, fire, and other culturally evolved methods of protecting against the cold reduce the selective pressure exerted by nature and allow a population to maintain a wider variety of body shapes or evolve toward body shape that meets a culturally evolved preference rather than one that is environmentally expedient (Newson et al. $2007:$ 462)

\subsection{Culture and personality}

Personalities affect culture and culture affects personality (Linton, 1936 : 464). The variation in personality traits between societies is of cultural origin (Ogburn \& Nimkoff, 1964 : 190). The cultural facet of the environment of any society is an important determinant both of the content and the structure of the personalities (Kluckhohn and Mowrer, 1944: 7). The personality of an individual change with his cultural role as well as the psycho-somatic constitution (Bidney, 1953: 342). 
Personality is the cultural attribute of human nature, but it is not identical with the latter (Bidney, 1953: 336). Kroeber also accepts the mutual influence of culture and personality. According to him (1948: 574) different kinds of culture produce different kinds of personalities and personalities also modify or exaggerated or maintenance culture. According to Ogburn and Nimkoff (1964: 199), the basic personality structure may be the result of family pattern and religion and other institutions are influenced by personality. Culture determines both the content and structure of personalities (Kroeber, 1944: 7). For example, Oedipus complex, a kind of attitude in which boy loves mother but hates father, is vary in different type of family organization (White, 1949 : 155). Total energy output and quality of output is the manifestation of emotion or temperament which is affected by cultural patterning (Gillin, 1948 : 666, 671). Both material and non-material culture affect the personality. For example, watch and cloak (material culture) encourage the habit of punctuality and value which is furnished by non-material culture affect the personality (Ogburn and Nimkoff, 1964 : 191-193). Culture derives all its qualities from their personalities and the interaction of personalities (Linton, 193 : 464). Cardiner (1945: 111) explains the culture-personality interrelationship as those primary institutions (the institutions from which child receives the experience such as household, child-rearing practice etc.) produce basic personality structure (permanent existence in the mental equipment of the individual) and basic personality structure which, in turn, produces secondary institutions (institutions develop as the result of the projective system such as religion, art etc.).

\subsection{Human biology and personality}

Human nature is genetically prior to personality (Bidney, 1953: 336). Personality is an attribute which human nature acquires through participation in a given culture (Bidney, 1953: 335). Race is the biological determinant of personality which manifests itself not only in terms of appearance but also in behavior (Kluckhohn and Mowrer, 1944: 7). Personality is not significantly different in different racial groups (Beals and Hoijer, 1913 : 198). Physical defects and disease limits contacts and consequent isolation may result in distorted personalities (Reuter, 1946 : 125). Endocrine balance set limits emotional manifestation (Gillin, 1948 : 666). The feebleminded are unable to develop full adult personalities because of their constitutional inability to learn (Gillin, 1948 : 669). Hypothyroid and hypo pituitary will develop different kinds of personality (Linton, $1936: 57$ ).
It is clearly understood that learned aspects of human life are not exclusively separate entities from the mind-body structure but different facets of the same object. Or, you can say, mind-body structure of man is the infrastructure upon which the superstructure of human nature, personality and culture is built. But, the superstructure is not passive in the sense that it also affects infrastructure. Human nature is the foundation of etic but not emic culture and when human nature is colored by culture again it is expressed as a personality characteristic of the person.

\section{REFERENCES}

[1] Bagby (1953) "Culture and the causes of culture" American anthropologist 55: 535-554.

[2] Beals, R. L. \& Hoijer, H. (1913) An introduction to anthropology N. Y. : The Macmillan Company.

[3] Bidney, D. (1944) "On the concept of culture and some cultural fallacies" American anthropologist 46: 30-44.

[4] --- (1947) "Human nature and the cultural process" American anthropologist 49: pp. 375-399.

--- (1953) Theoretical anthropology N. Y. : Columbia University Press.

[5] Cardiner, A. (1945) "The concept of basic personality structure as an operational tool in the social sciences" in Linton, R. (ed.) The science of man in the world crisis $\mathrm{N}$. Y.: Columbia University Press, pp. 107-122.

[6] Count, E. W. (1958) "The biological basis of human sociality" American anthropologist 60: pp. 1049-1085.

[7] Gillin, J. L. (1948) Cultural sociology : a revision of an introduction to sociology N. Y.: The Macmillan Company.

[8] Hiebert, G. (1976) Cultural anthropology N. Y : J. B. Libbincott Company.

[9] Hofstede, G. et al (2010) Culture and organization : software of the mind $\mathrm{NY}$ : McGraw-Hill.

[10] Kluckhohn, C. and Mowrer, O. H. (1944) "Culture and personality: a conceptual scheme" American anthropologist 46.1.1: pp.1-29.

[11] Kroeber, A. L. (1948) Anthropology N. Y.: Harcourt, Brace and Company.

[12] Linton, R. (1936) The study of man : an introduction N. Y.: Appleton-Century-Crofts, INC.

[13] Lowie, R. (1917) Culture and ethnology N.Y. : Boni \& Liveright.

[14] --- (1947) An introduction to cultural anthropology N. Y. : Rinehart \& Company.

[15] Malinowski, B. (1944). A scientific theory of culture, and other essays. University of North Carolina Press.

[16] Newson, L., Richerson, P.J., \& Boyd, R. (2007). Cultural evolution and the shaping of cultural diversity. In S. Kitayama \& D. Cohen (Eds.) Handbook of cultural psychology (pp. 454-476). N. Y: Guilford Press.

[17] Ogburn, W. F. \& Nimkoff, M. F. (1964) A handbook of sociology London : Routledge \& Kegan Paul.

\section{CONCLUSION}


[18] Reuter, E. B. (1946) "Race and culture" in Lee, A. M. (ed.) New outline of the principles of sociology N. Y.: Barnes \& Noble, INC. pp. 121-166.

[19] Schell, L. M. (2014) "Culture, urbanism and changing human biology" Glob Bioet 25.2: pp. 147-154.

[20] Shore, B. (2001) "Human diversity and human nature : the life and times of a false dichotomy" in Neil. R. (ed.) Being human Berlin : Walter de Gruyter, pp. 1-43.

[21] Warden, C. J. (1936) The emergence of human culture $\mathrm{N}$. Y.: The Macmillan Company.

[22] White, L. A. (1949) The science of culture : a study of man and civilization N. Y. : Grove Press.

[23] Young, K. (1949) Sociology : a study of society and culture N. Y.: American Book Company. 